\title{
Determination of bacteria migration speed through urinary catheter systems in case of urostomy
}

\author{
FHH Brill ${ }^{1 *}, \mathrm{H}$ Braunwarth ${ }^{2}, \mathrm{D}$ Hegeholz ${ }^{2}$, W Droste ${ }^{3}$ \\ From 3rd International Conference on Prevention and Infection Control (ICPIC 2015) \\ Geneva, Switzerland. 16-19 June 2015
}

\section{Introduction}

Following a urostomy, the main aim from a hygiene perspective is to prevent bacteria from accumulating in the artificial drainage system (splint), e.g. as a result of contaminated urine. A return stop in the urostomy pouch keeps this risk to a minimum. In practice, however, splints are often pushed through the return stop to keep them more securely in place, which means that they may come into direct contact with the potentially contaminated urine.

\section{Objectives}

The Objective was to study the migration speed of clinically-relevant bacteria in catheter systems used after urostomy.

\section{Methods}

We carried out an in-vitro experiment in a commerciallyavailable uriniferous system applied in a urostomy. This involved connecting two storage vessels: the first containing splints which had previously been rinsed once with artificial urine; and the second containing a bacterial suspension of the test bacteria (E. coli, $P$. aeruginosa and $P$. mirabilis), which had previously been soaked in artificial, sterile urine. The two storage vessels were inclubated at $36{ }^{\circ} \mathrm{C}$ for 24 to 72 hours. The splints were cut into segments of $5 \mathrm{~cm}$ after 24 hours, 48 hours and 72 hours. The colony-forming units (CFU) on the pieces were determined. Each experiment was carried out nine times before the average values and standard deviations were subsequently determined.

\section{Results}

After 24 hours the bacteria migrated into the splint, on average, as follows: E. coli $26.7 \mathrm{~cm} \pm 20.6$, S. aureus
$27.2 \mathrm{~cm} \pm 10.6$ and P. mirabilis $12.8 \mathrm{~cm} \pm 16.2$. After 48 hours the bacteria migrated as follows: $35.0 \mathrm{~cm} \pm$ 11.2 (E. coli), $51.7 \mathrm{~cm} \pm 7.5$ (S. aureus) and $41.7 \mathrm{~cm} \pm$ 23.6 (P. mirabilis). The results after 72 hours were: $49.4 \mathrm{~cm} \pm 14.5$ (E. coli), $60 \mathrm{~cm} \pm 16.0$ (S. aureus) and $67.8 \mathrm{~cm} \pm 3.6$ (P. mirabilis).

\section{Conclusion}

The test bacteria grew relatively quickly through the catheter. It is likely that bacteria would grow through catheters with $80 \mathrm{~cm}$ length within a week at the latest. In this case, these is a direct infection risk for bladder and kidneys of the patient. These results should be taken into consideration during clinical use of the catheter systems in case urostomy.

\section{Disclosure of interest}

F. Brill Grant/Research support from: partially by Coloplast; Germany., H. Braunwarth Employee of: Coloplast, Germany., D. Hegeholz Employee of: Coloplast, Germany., W. Droste: None declared.

\section{Authors' details \\ ${ }^{1}$ Dr. Brill + Partner Gmbh Instiute for Hygiene and Microbiology, Hamburg, Germany. ${ }^{2}$ Coloplast GmbH, Hamburg, Germany. ${ }^{3}$ Private Consultant, Selm,} Germany.

Published: 16 June 2015

doi:10.1186/2047-2994-4-S1-P219

Cite this article as: Brill et al:: Determination of bacteria migration speed through urinary catheter systems in case of urostomy. Antimicrobial Resistance and Infection Control 2015 4(Suppl 1):P219. 